\title{
Deadly Gastrointestinal Parasites as a Productive Hazard of Sheep
}

\author{
Nazik Z Eisa* \\ Department of Animal Production, University of Gezira, Sudan
}

Submission: May 15, 2017; Published: June 23, 2017

*Corresponding author: Nazik Z Eisa, Department of Animal Production, Faculty of Agriculture, University of Gezira, Wad Medani, Sudan, Tel: 0125151512, Email: eisanazik@uofg.edu.sd

\section{Mini Review}

Sheep are susceptible to endoparasitic nematodes, roundworms, tapeworms, and coccidia which are very pathogenic [1]. This is suggested to be due to a combination of several factors such as climate, energy level of the diet, age, number of ingested larvae and sheep general health [2,3] reported that losses of livestock and income through death and condemnation of carcasses and viscera is the most direct and readily appreciated social and economic consequences of parasitism in tropical and subtropical areas. Helmithiasis, specially gastro-enteritis constitutes a serious cause of limitation to the productivity of small ruminants throughout the world due to the associated morbidity, mortality, cost of treatment and control measures [4]. In Ethiopian highlands, crossbreeding of indigenous Menz sheep with exotic Awassi sheep had problems of high mortality of the distributed rams due to internal parasites [5]. Gastrointestinal parasitic infection associated with reduced appetite, poor weight gains, diarrhea, and death [6]. Researchers have shown that poorly nourished animals are more susceptible to infection with parasites. This could be due to a lack of overall protein and energy or a poorly balanced diet, deficient in minerals [1]. Part of the severity comes due to the fact that many larval stages can survive for a relatively long period of time in the dehydrated stage and once moistened can re-hydrate and become motile again [7]. The female's extraordinary output of eggs is partly responsible for the explosive nature of outbreaks, especially in favorable weather conditions [8]. Trichostrongyles are associated with extensive damage to the duodenal mucosa and with signs of generalized enteritis, including haemorrhages, oedema and plasma protein loss into the intestinal lumen, and subsequent hypo-albuminaemia and hypo-proteinaemia [9]. The feeding and migratory activities of these parasites are direct causes of production loss, because they remove blood and nutrients and cause tissue damage. Cestode parasites cause disease through the development and space-occupying nature. Although, Edwards, (2005) stated that cestode tapeworm parasite, Monezia expansa, which parasitize sheep as its final host, passively absorbs nutrients from the intestinal digesta and has few, if any, adverse effects on productivity, It still causes production loss, due to the considerable cost incurred by its treatment and management. On the other hand, [10] stated that nematodes are more serious in the main sheep-raising areas [11]. Stated that sheep gastrointestinal infection causes severe reduction in daily weight gain and demonstrates awful food conversion. Gastrointestinal parasites could cause mortality, stunted growth, unthriftness and partial or complete condemnations of the carcasses at the slaughterhouses [12]. Parasitologists have mainly been concerned with understanding the biology of the host-parasite system. Parasites considerably and harmfully influence host lifehistory characteristics and vice versa [13]. There is unarguable evidence that parasites are progressively becoming resistant to all of the major chemical compounds used in the battle against them [14]. Repeated treatments to the same type of drench selects these resistant worms until they make up a significant proportion of the worm population [15]. This has obviously been necessary for the logical development of measures for the prevention and treatment of parasitic diseases. However, control procedures, based on epidemiological principles, have seldom been tested in the context of realistic systems of production [16]. In Sudan, it is difficult to practice the method of controlling internal parasites depending on rotational grazing [17]. Accordingly, helminth control depends completely on the use of anthelmintics. However, the efficacy of these drugs has been reduced, because of resistant nematodes strains $[18,19]$ was the first scientist to conduct a search about injectable Ivomec which exhibited $100 \%$ efficacy against gastro-intestinal nematodes of naturally infected sheep in Sudan [20-23].

\section{References}

1. Bassetto CC, Dasilva BF, Fernandoes S, Do Amarante AF (2009) Pasture contamination with infective larvae of gastrointestinal nematodes after grazing by sheep resistant or susceptible to parasitic infection. Rev Bras Parasitol Vet 18: 63-68. 
2. Blackburn HD, Paiva SR, Wildeus S, Getz W, Waldron D, et al (2011) Genetic Structure and Diversity among U. S. Sheep Breeds: Identification of the Major Gene Pools. J Anim Sci 89(8): 2336-2348.

3. Harfoush MA, Abdel AA, El-Seify MA (2010) Resistance of gastrointestinal nematodes of sheep to some anthelmintics. J Egypt Soc Parasitol 40(2): 377-382.

4. Silvestre A, Chartier C, Sauve C, Cabaret J (2000) Relationship between helminth species diversity, intensity of infection and breeding management in dairy goats. Vet Parasitol 94(1-2): 91-105.

5. Tibbo M, Aragaw K, Philipsson J, Malmfors B, Nasholm A, et al. (2008) A field trial of production and financial consequences of helminthosis control in sheep production in Ethiopia. Prev Vet Med 84(1-2): 152160.

6. Coop RL, Jackson F, Graham RB (1988) Influence of two levels of concurrentinfection with Ostertagia circumcinctaand Trichostrongylus vitrinus on the growth performance of lambs. Res Vet Sci 45: 275-280.

7. Joan B (2005) Management of Barber pole Worm in Sheep and Goats in the Southern US. Dale Bumpers Small Farms Research Center, USA.

8. Taylor MA, Coop RL, Wall RL (2007) Veterinary Parasitology ( $3^{\text {rd }}$ edn), Blackwell Publishing England, UK.

9. Florian R, Aaron RJ, Robin BG (2013) Impact of gastrointestinal parasitic nematodes of sheep, and the role of advanced molecular tools for exploring epidemiology and drug resistance - an Australian perspective. Parasites and Vectors 6: 153-202.

10. Emmanuel BW (2013) Gastrointestinal parasites in ruminants at selected abattoirs in the Greater Accra region, University of Ghana, Ghana.

11. Cardia DF, Rocha-Oliveira RA, Tsunemi MH, Amarante AF (2012) Immune response and performance of growing Santa Ines lambs to artificial Trichostrongylus colubriformis infections. Vet Parasitol 182(2-4): 248-258.

12. Domke AV, Chrtier C, Gjerde B, Leine N, Vatn S, et al. (2011) Worm control practice against gastro-intestinal parasites in Norwegian sheep and goat flocks. Acta Vet Scand 53: 29.
13. Cooper N, Kamilar JM, Nunn CL (2012) Host longevity and parasite species richness in mammals. PLoS One 7(8): e42190.

14. Sissay MM, Asefa A, Uggla A, Waller PJ (2006) Anti-helmintic resistance of nematode parasites of small ruminants in eastern Ethiopia: Exploitation of refugia to restore anti-helmintic efficacy. Vet. Parasitol 135: $337-346$

15. Waller PJ (1997) Nematode parasite control of livestock in the tropics/ subtropics: the need for novel approaches. Int J Parasitol 27(10): 11931201.

16. Morley FHW, Donald AD (1980) Economic Impact Farm management and systems of helminthes control. Veterinary Parasitology Elsevier Scientific Publishing Company, Amsterdam - Printed in The Netherlands 6: 105-134.

17. Barger IA (1999) The role of epidemiological knowledge and grazing management for helminth control for small ruminants. International Journal for Parasitology 29: 41-47.

18. Jabbar AZ, Igbal D, Kerboeuf G, Mohammed MN, Khan MA (2006) Antihelmintic resistance the state of play revisited. Life Science. 79: 24132431.

19. Artho R, Schnyder M, Kohler L, Torgerson PR, Kertzberg H (2007) Ivermectin-resistace in gastrointestinal nematodes of Boer goats and Dorper sheep in Switzerland. Vet Parasitology 144(1-2): 68-73.

20. Abdalla HS (1998) Effects of endoparasites on the growth rate of Sudanese sheep and cattle. Trop Anim Health Prod 21(1): 3.

21. Eduardo B, Marilia MM, Romário CL (2011) Hemogram of buffaloes (bubalus bubalis) wormed and nonwormed by helminthes. Vet Rec 18 102-110.

22. Tibbo M, Aragaw K, Philipsson J, Malmfors B, Nasholm A, et al. (2008) A field trial of production and financial consequences of helminthosis control in sheep production in Ethiopia. Prev Vet Med 84(1-2): 152160.

23. Waller PJ (1994) The development of anti-helmintic resistance in ruminant livestock. Acta Trop 56(2-3): 233-243.

\section{Your next submission with Juniper Publishers} will reach you the below assets

- Quality Editorial service

- Swift Peer Review

- Reprints availability

- E-prints Service

- Manuscript Podcast for convenient understanding

- Global attainment for your research

- Manuscript accessibility in different formats

(Pdf, E-pub, Full Text, Audio)

- Unceasing customer service

Track the below URL for one-step submission https://juniperpublishers.com/online-submission.php 